\title{
Quantitative ABCD Analysis of IEDRA Model of Placement Determination
}

\author{
Varun Shenoy, ${ }^{1} \&$ P. S. Aithal ${ }^{2}$ \\ 1, 2 Srinivas Institute of Management Studies, Srinivas University, Mangalore - 575 001, \\ INDIA. \\ E-Mail: varun_shenoy@rediffmail.com
}

Type of the Paper: Research Analysis.

Type of Review: Peer Reviewed.

Indexed In: OpenAIRE.

DOI: http://dx.doi.org/10.5281/zenodo.1133691.

Google Scholar Citation: $\underline{\text { IJCSBE }}$

\section{How to Cite this Paper:}

Shenoy Varun., \& Aithal, P. S. (2017). Quantitative ABCD Analysis of IEDRA Model of Placement Determination. International Journal of Case Studies in Business, IT and Education (IJCSBE), 1(2), 103-113. DOI: http://dx.doi.org/10.5281/zenodo.1133691.

International Journal of Case Studies in Business, IT and Education (IJCSBE)

A Refereed International Journal of Srinivas University, India.

(C) With Authors.

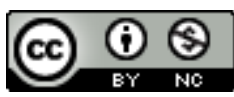

This work is licensed under a Creative Commons Attribution-Non Commercial 4.0 International License subject to proper citation to the publication source of the work.

Disclaimer: The scholarly papers as reviewed and published by the Srinivas Publications (S.P.), India are the views and opinions of their respective authors and are not the views or opinions of the S.P. The S.P. disclaims of any harm or loss caused due to the published content to any party. 


\title{
Quantitative ABCD Analysis of IEDRA Model of Placement Determination
}

\author{
Varun Shenoy, ${ }^{1} \&$ P. S. Aithal ${ }^{2}$ \\ 1, 2 Srinivas Institute of Management Studies, Srinivas University, Mangalore - 575001 , \\ INDIA. \\ E-Mail: varun_shenoy@rediffmail.com
}

\begin{abstract}
The current technological and digital era has always directed campus recruitment process towards eruption of paradigm shifts matching new systems of industrial workforce engagements. The dilemma of job seeking graduates today in campus has ever more convoluted towards the rapid changes in industry and employment market. IEDRA Model of Student Campus Placement Realization was a more comprehensive study undertaken by Shenoy \& Aithal (2017) to resolve such a dilemma of students. Therefore here, a brief study is undertaken to discover practical viabilities, understand the usefulness, resourcefulness and universal applications of IEDRA Model of campus placement determination towards concerned stakeholders. A new model of framework analysis named ABCD analysis developed by Aithal et al. (2015) is adopted here for arriving at appropriate theory, hypothesis or postulate constructs regarding the ubiquitous appeal of the IEDRA Framework.
\end{abstract}

Keywords: ABCD framework, Online Campus Recruitment, IEDRA Model, Model elemental analysis, Employment Placements.

\section{INTRODUCTION TO IEDRA FRAMEWORK AND NEED FOR ITS MODEL ANALYSIS :}

The present higher education system is more industry oriented where focus is on to ensure that graduating student delivers at work with very minimal support and training to achieve cost efficiency and time savings for the recruiter. However, with the widespread prevalence of online placements in campus placement process like never before, securing an employment with employer has become even more complex paradigm for the students given the fact of vulnerable psychology of young student minds as well volatile industry fluctuations. Therefore to solve this dilemma, Shenoy \& Aithal (2017) constructed IEDRA Model of student placement determination [1]. IEDRA is an abbreviation that stands for Interested, Eligible, Deserving, Registered and Acceptability in a constructual format. Application of IEDRA Framework ensures in a structured list of interested, eligible, deserving, registered and acceptable students/graduates for campus interview-recruitment process in an organized matrix. The entire analysis is divided under various issues and focus are for employment seeking students or graduates and various deployment factors affecting the process or concept can be recognized and ascertained under each issue by identifying suitable critical effective characteristics. This concept or phenomenon examination technique being very simple, gives effective guidelines to recognize and find the effectiveness of any interview or placement process and new ideas constructed further there on if any. Lastly, as per the IEDRA Model, once the candidate meets all the factor constructs of the framework; he/she shall have to attend actual interviews or mock interviews where the framework's clause of appraisal will be implemented for testing the practically for selfdetermining employment securing chances or likelihood of the candidate. It is a well-known and accepted fact in research circles that any new model or framework propounded becomes effective valid only if it is scientifically tested or analysed. While we know various known methodologies are used to examine important strategic processes and business operations like Competitive Profile Matrix (CPM) analysis and EFE \& IFE Matrices [2], Balanced Score card [3], SWOT Analysis [4], Porter's Five Forces Model [5], BCG Growth Share Matrix [6], Mckinsey 7S Model [7], PESTLE Analysis [8], we also have recently introduced Research Productivity measuring ABC Model [9], E-Interview Training BOX Model [10] in field of E-HRM and again ABCD Frameworks [11-12] to analyse 
operating models and decision areas, a research necessity was also born here to analyse the new rising paradigm of campus placements or recruitments understanding process in present digital world i.e. IEDRA Model of Placement Determination. As a matter of practical, experimental, and futuristic new approach, we have also adopted the new recently discovered and rapidly emerging new ABCD Framework of Model Analysis of IEDRA Model for arriving at key characteristics that reflects the possible need, requirement and inevitability of its utilization in near future.

\section{ABOUT ABCD FRAMEWORK :}

ABCD Model is a methodology to understand various models and research their effectiveness in stakeholders' value provision. ABCD signifies A for Advantages, B for Benefits, and C for Constraints and D for Disadvantages. The technique developed by Aithal et al. (2015) whose usage results in a structured analysis of primary advantages, benefits, constraints, and disadvantages in an organized format. The entire analysis is further classified under various focus/issue areas and various operating factors affecting the functionalities. The identified concepts are then studied and analysed under each item by locating their critical characteristics. This analysing methodology being very simple gives effective guidelines to identify and analyse the applicability and effectiveness of any models and new rationale developed. In qualitative research using ABCD Analysis, the system, concept, strategy, model, technology, and idea or plan is further examined by identifying constitutional critical criteria. In the quantitative analysis using ABCD framework, the relevant score weightage is assigned to each constituent critical characteristic under each construct, through adopting empirical analysis, the total score is calculated under each construct and by evaluating the scores, the plan or concept, idea, system, technology, strategy can be adopted or denied. Thus, ABCD analysis Model can be used as a primary analysis technique in various areas or sectors and is a simple but organized analysing tool for business or operating models, systems, concepts, ideas, plan, technology, and strategic analysis. In evidence of support here on to a study entitled ABCD Framework Analysis for Business Models, strategies, Operating Concepts \& Business Systems [13], the author briefly discussed the detailed methodology for quantitative methods and explained how this model can be used for four specific instances namely Business model, Business strategy, Operational concept and Functional systems. In this study, ABCD framework is compared with other known analysing techniques like Balanced Score card, SWOT Analysis, Porter's Five Forces Model, Competitive Profile Matrix (CPM) analysis, EFE \& IFE Matrices, BCG analysing frameworks, PESTLE Analysis and proved the validity of ABCD analysing technique.

\section{LITERATURE REVIEW ON ANALYSIS USING ABCD FRAMEWORK :}

The ABCD Model is used to analyse the characteristics of "Working from Home" e-business model [14]. In this study, based on various attributes which decide the Work from Home system, a framework of various attributes and their constituent critical elements influencing under various stakeholders' perspectives and system requirements were derived from a qualitative data collection channel namely focus group interactions. It was discovered that the factors supporting advantages and benefits were more effective compared to constraints and disadvantages of this model, so that work from home model has the potential to become more popular from the perspective of stakeholders in future. ABCD analysis Model is used for studying Black ocean strategy concept [15]. The determining factors \& their constituent critical factors affecting this concept adopted in some of the organizations provided for quick escape from the obstacles which were recognized for stakeholders under the four constructs - advantages, benefits, constraints, and disadvantages.

ABCD Model has also been used for analysing a concept "Higher Education Stage Model". The characteristics of the concept are evaluated based on identifying and ascertaining the advantages, benefits, constraints, and disadvantages. The fall out supported the logic of using ABCD framework methodology in any concept/idea performance evaluation [16]. ABCD analysis methodology is also used for studying National Assessment and Accreditation Council (NAAC) accreditation procedure on higher educational institutions [17]. The different elements of the NAAC accreditation process is appraised based on recognizing and studying the constructs relating to chosen issues like Institutional issues, Faculty performance issues, student development/progression issues, social/ environmental/ community engagement issues, Infrastructure and Learning resources, and Issues on Innovations 
Creativity and Best Practices. The influencing factors under these issues resulted in using focus group interactions and the constituent critical elements under each factor were identified. The findings supported the logic of applying ABCD Model in any System/concept of institutional performance appraisals. Application of ABCD Framework on Private University System in India is another study published using this framework in which for six determinant issues related to the functioning of a varsity were chosen. These are Institutional aspects, Students Progression, Faculty development, Societal \& other stakeholders' issues, Leadership, Governance and Issues on Innovations and Best Practices. Four key issues were identified under each of these and critical constituent elements under these attributes were worked out. Through this analysis, 192 critical constituent elements satisfied the success of a private university were explored [18]. The Scholar also undertook an analysis of India's New National Institutional Ranking Framework (NIRF) System using ABCD Analysis, where the published ranking process was appraised under four constructs Advantages, Benefits, Constraints, and Disadvantages, considering all crucial issues in primary areas through studying the major issues and recognizing the critical constituent factors and concluded that NIRF provides a comprehensive ranking suitable for higher educational institutions and takes care of many small and subtle aspects comparable to quality assessment criterion of National Assessment and Accreditation Council [19].

In area of Science, The ABCD Analysis is used for elemental and factor analysis of the utilization of dye-doped polymer films for photonic applicability [20]. The different influencing criterions under the determinant issues like Materials, Application Issues, and Commercialization challenges, Production/Service providers Issues, Customer Issues, and Environmental/Social Issues were identified. The constituent critical characteristics of these factors were listed under the ABCD architecture i.e. advantages, benefits, constraints and disadvantages and subsequently tabulated. The study resulted in outcome of about 204 critical constituent elements which proves the triumph of this analysis methodology.

\section{ABCD LISTING OF IEDRA MODEL OF STUDENT PLACEMENT DETERMINATION :}

Well, a focus group of 20 MBA Student samples who implemented IEDRA Model were chosen from SIMS, Pandeshwar, Mangalore to weight and aid the research. Upon interactions and discussions with Focus Group under the ABCD Architecture, the responses from samples bought in the following Advantages, Benefits, Constraints, and Disadvantages [21-31] of IEDRA Model of Student Placement Determination which are listed as below :

\subsection{Advantages :}

The IEDRA Model of Student Placement Determination is highly advantageous for students owing to below factors :

(1) Student will get to know about his inherent chances of getting selected in Campus Interview or Recruitment Process.

(2) The IEDRA Framework reduces or eradicates the psychological dilemma of students on various placement apprehensions.

(3) The Model is easy to implement by student during his academic tenure.

(4) The Model is flexible and is highly adaptive in any conditions for the students even while preparing for interviews post the completion of their graduation.

(5) The administration of IEDRA Model is trouble free anytime anywhere even can be functional from home.

\subsection{Benefits:}

The IEDRA Model of Student Placement Determination is greatly beneficial for students owing to below factors :

(1) A Student can view his appraisal and determine his/her actual position and performance in interviews under the IEDRA Model Score Card and further decide on his/her next move.

(2) Student will have a readymade steady roadmap in his/her hand as to the criteria to be observed for getting selected or recruited in campus interviews.

(3) IEDRA Model fills the gap of a lack of a robust standard or measuring yardstick for solution to ages old student dilemma of whether he/she will get placement/job or not during final year of graduation or even immediately post completion of education. 
(4) A job seeking student at campus will understand his/her weak points or problem zone at each stage of placement process as per each construct of IEDRA Model triggering him/her to work on the same during their quest for securing employment placement during final end semester.

(5) The IEDRA Model facilitates self-supervision for students and also easily alignable into their routine time-table.

\subsection{Constraints:}

The IEDRA Model of Student Placement Determination can constrain campus job seeking students owing to below factors:

(1) Students may ignore the applicability and relevancy of the Model owing to various psychological biases as well as their academic commitments.

(2) The IEDRA Model of Student placement ascertainment being very qualitative, is also very probability and approximation oriented.

(3) Students may be highly apathetic towards the IEDRA concept owing general under confidence to face industry and lack courage to prepare for the job interviews.

(4) Lack of Interest and Age immaturity may curtail a job aspiring student to full the comprehend the model and its constructs towards productive implementation.

(5) The Model is still far behind from being popular or even as a universally accepted guiding framework or model for determining candidate's job seeking qualification capabilities or capacities.

\subsection{Disadvantages :}

The IEDRA Model of Student Placement Determination is disadvantageous for students under below factors:

(1) The Model would be extra load or target setting for students in addition to their academic commitments.

(2) The Model lacks numerical quantification.

(3) The Volatile and Vulnerable minds of young students may lack adoption of the concept.

(4) The procrastinating attitude would not allow the job aspiring student to take initiative in implementing and following the IEDRA constructs.

(5) The personal ignorance and innocence of the student may lack trust in the IEDRA concept for ascertaining the possibility of placement achievement.

\section{ABCD FRAMEWORK APPLIED TO IEDRA MODEL OF STUDENT PLACEMENT DETERMINATION :}

The below table depicts the key attributes and determinant issues identified for IEDRA Model under ABCD Analysis based upon direct interaction with focus group [32- 39].

Table 1 : Determining Issues and Deciding Factors applied to IEDRA Model of Student Placement Determination

\begin{tabular}{|c|c|c|c|c|}
\hline Key Attributes & Advantages & Benefits & Constraints & Disadvantages \\
\hline Model Schedule & $\begin{array}{c}\text { Easy } \\
\text { Implementation }\end{array}$ & $\begin{array}{c}\text { Organized and } \\
\text { Methodical }\end{array}$ & $\begin{array}{c}\text { Student Casual } \\
\text { Take }\end{array}$ & Extra Load \\
\hline Model Flexibility & Highly Adaptive & Trouble Free & $\begin{array}{c}\text { Time } \\
\text { Consuming }\end{array}$ & $\begin{array}{c}\text { Lacks Numerical } \\
\text { Quantification for } \\
\text { Constructs }\end{array}$ \\
\hline Model Administration & $\begin{array}{l}\text { Anytime/ } \\
\text { Anywhere }\end{array}$ & $\begin{array}{c}\text { Self- } \\
\text { Supervision }\end{array}$ & Student Apathy & Lack of Adoption \\
\hline $\begin{array}{c}\text { Overall Model Usage, } \\
\text { Relevance and } \\
\text { Applicability }\end{array}$ & $\begin{array}{c}\text { Career } \\
\text { Conducive }\end{array}$ & $\begin{array}{c}\text { Easy } \\
\text { Alignment }\end{array}$ & $\begin{array}{l}\text { Inability to } \\
\text { comprehend the } \\
\text { Model }\end{array}$ & Lack of Initiative \\
\hline
\end{tabular}




\section{CRITICAL CONSTITUENT ELEMENTS FOR IEDRA MODEL AS PER ABCD} ANALYSIS:

This section discusses in detail about the various critical constituent elements for each key attribute under the focus area belonging to the construct of ABCD Model. Application of Weights are done accordingly by the focus group. The Weightage Ranking is denoted as below :

3 - Satisfactory

2 - Neutral

1 - Not Satisfactory

The below table depicts the Advantageous Factors of IEDRA Model and their critical constituent elements bought out by the Focus Groups :

Table 2 : Advantageous Factors of IEDRA Model and their critical constituent elements

\begin{tabular}{|c|c|c|c|}
\hline $\begin{array}{l}\text { Focus } \\
\text { Area }\end{array}$ & Key Attributes & $\begin{array}{c}\text { Advantageous } \\
\text { Factors Affecting } \\
\text { Determinant Issues }\end{array}$ & $\begin{array}{c}\text { Critical Constituent Elements along } \\
\text { with Ranking Scores }\end{array}$ \\
\hline \multirow{31}{*}{ Student } & \multirow{8}{*}{ Model Schedule } & \multirow{8}{*}{ Easy Implementation } & Placement Curriculum (3) \\
\hline & & & Simple Comprehension (3) \\
\hline & & & Schedule Friendly (3) \\
\hline & & & Simple Follow-ups (3) \\
\hline & & & Facilitates Goal Setting (3) \\
\hline & & & Ensures Career Planning (3) \\
\hline & & & Communication Friendly (3) \\
\hline & & & Technologically Compatible (3) \\
\hline & \multirow{10}{*}{$\begin{array}{l}\text { Model } \\
\text { Flexibility }\end{array}$} & \multirow{10}{*}{ Highly Adaptive } & Student Friendly (3) \\
\hline & & & Positively Realisable (3) \\
\hline & & & Social Media Friendly (3) \\
\hline & & & Interview Focused (3) \\
\hline & & & Selection Centred (3) \\
\hline & & & Recruitment Oriented (3) \\
\hline & & & Possesses Universal Appeal (3) \\
\hline & & & Simple Terms (3) \\
\hline & & & Effective Conditions (3) \\
\hline & & & $\begin{array}{l}\text { Information and Communication } \\
\text { Technology Oriented (3) }\end{array}$ \\
\hline & \multirow{7}{*}{$\begin{array}{c}\text { Model } \\
\text { Administration }\end{array}$} & \multirow{7}{*}{ Anytime/Anywhere } & Easy Supervision (3) \\
\hline & & & Work from Home (3) \\
\hline & & & Supports Online Placements (3) \\
\hline & & & E-Recruitment Friendly (3) \\
\hline & & & Policy Friendly (3) \\
\hline & & & Self-Control and Direction (3) \\
\hline & & & Regulation Friendly (3) \\
\hline & \multirow{6}{*}{$\begin{array}{l}\text { Overall Model } \\
\text { Usage, } \\
\text { Relevance and } \\
\text { Applicability }\end{array}$} & \multirow{6}{*}{ Career Conducive } & Fulfils Campus Objectives (3) \\
\hline & & & Achieves Placement Objectives (3) \\
\hline & & & Realises Placement Aims (3) \\
\hline & & & Sets Benchmark (3) \\
\hline & & & Effort Contentment (3) \\
\hline & & & Professional Excellence (3) \\
\hline
\end{tabular}

The below table depicts the Benefit Factors of IEDRA Model and their critical constituent elements bought out by the Focus Groups : 
Table 3 : Benefit Factors of IEDRA Model and their critical constituent elements :

\begin{tabular}{|c|c|c|c|}
\hline $\begin{array}{l}\text { Focus } \\
\text { Area }\end{array}$ & Key Attributes & $\begin{array}{c}\text { Beneficial } \\
\text { Factors Affecting } \\
\text { Determinant Issues } \\
\end{array}$ & $\begin{array}{c}\text { Critical Constituent Elements along } \\
\text { with Ranking Scores }\end{array}$ \\
\hline \multirow{21}{*}{ Student } & \multirow{6}{*}{ Model Schedule } & \multirow{6}{*}{ Organized and Methodical } & Achievable Modules (3) \\
\hline & & & Structured Architecture (3) \\
\hline & & & Quick Reference Guide (3) \\
\hline & & & Confidence Building Model (3) \\
\hline & & & Convenient Preparation Tool (3) \\
\hline & & & Priority Oriented (3) \\
\hline & \multirow{5}{*}{$\begin{array}{l}\text { Model } \\
\text { Flexibility }\end{array}$} & \multirow{5}{*}{ Trouble Free } & Easy Referencing (3) \\
\hline & & & Readymade Checklist (3) \\
\hline & & & Detailed Guidance (3) \\
\hline & & & Re-usability (3) \\
\hline & & & Solution Based (3) \\
\hline & \multirow{4}{*}{$\begin{array}{c}\text { Model } \\
\text { Administration }\end{array}$} & \multirow{4}{*}{ Self-Supervision } & Detailed Constructs (3) \\
\hline & & & Easy Self-Guidance (3) \\
\hline & & & Self-Placement Planning (3) \\
\hline & & & User Friendly Appraisal (3) \\
\hline & \multirow{6}{*}{$\begin{array}{l}\text { Overall Model } \\
\text { Usage, } \\
\text { Relevance and } \\
\text { Applicability }\end{array}$} & \multirow{6}{*}{ Easy Alignment } & Easy Adoption (3) \\
\hline & & & Simple Functionalities (3) \\
\hline & & & Facilitates Training Designs (3) \\
\hline & & & Industry Synchronisation (3) \\
\hline & & & Facilitates Networking (3) \\
\hline & & & E-Placement Compatible (3) \\
\hline
\end{tabular}

The below table depicts the Constraints Factors of IEDRA Model and their critical constituent elements bought out by the Focus Groups :

Table 4 : Constraint Factors of IEDRA Model and their critical constituent elements

\begin{tabular}{|c|c|c|c|}
\hline $\begin{array}{l}\text { Focus } \\
\text { Area }\end{array}$ & $\begin{array}{l}\text { Key } \\
\text { Attributes }\end{array}$ & $\begin{array}{c}\text { Constraint } \\
\text { Factors Affecting } \\
\text { Determinant Issues }\end{array}$ & $\begin{array}{c}\text { Critical Constituent Elements along with } \\
\text { Ranking Scores }\end{array}$ \\
\hline \multirow{17}{*}{ Student } & \multirow{5}{*}{$\begin{array}{l}\text { Model } \\
\text { Schedule }\end{array}$} & \multirow{5}{*}{ Student Casual Take } & Lack of Implementation Commitments (2) \\
\hline & & & No Revision Modules (1) \\
\hline & & & Focus Constraints (2) \\
\hline & & & Student Rebel Attitude (2) \\
\hline & & & Limited follow-ups (2) \\
\hline & \multirow{6}{*}{$\begin{array}{l}\text { Model } \\
\text { Flexibility }\end{array}$} & \multirow{6}{*}{ Time Consuming } & Preparation takes time (2) \\
\hline & & & Burdensome Schedule (2) \\
\hline & & & Lengthy Performance Measure (1) \\
\hline & & & Probability Oriented (2) \\
\hline & & & Prolonged Simulations (2) \\
\hline & & & Tedious Preparations (2) \\
\hline & \multirow{6}{*}{$\begin{array}{c}\text { Model } \\
\text { Administration }\end{array}$} & \multirow{6}{*}{ Student Apathy } & Passiveness to Escalate (2) \\
\hline & & & Enervation towards Interviews (2) \\
\hline & & & Lassitude towards Implementation (2) \\
\hline & & & Timidity to face Industry (2) \\
\hline & & & Persisting Negligence (2) \\
\hline & & & Midway Deviations (2) \\
\hline
\end{tabular}




\begin{tabular}{|c|c|c|}
\hline \multirow{7}{*}{$\begin{array}{l}\text { Overall Model } \\
\text { Usage, } \\
\text { Relevance and } \\
\text { Applicability }\end{array}$} & \multirow{7}{*}{$\begin{array}{l}\text { Inability to } \\
\text { Comprehend the } \\
\text { Model }\end{array}$} & Lack of Content Perception (1) \\
\hline & & Disloyalty for the Concept (2) \\
\hline & & Age Immaturity (2) \\
\hline & & Lack of Interest (2) \\
\hline & & External Distractions (2) \\
\hline & & Careless Attitude (2) \\
\hline & & No Botheration (2) \\
\hline
\end{tabular}

The below table depicts the Disadvantageous Factors of IEDRA Model and their critical constituent elements bought out by the Focus Groups :

Table 5: Disadvantageous Factors of IEDRA Model and their critical constituent elements :

\begin{tabular}{|c|c|c|c|}
\hline $\begin{array}{l}\text { Focus } \\
\text { Area }\end{array}$ & Key Attributes & $\begin{array}{l}\text { Disadvantageous } \\
\text { Factors Affecting } \\
\text { Determinant Issues }\end{array}$ & $\begin{array}{l}\text { Critical Constituent Elements along } \\
\text { with Ranking Scores }\end{array}$ \\
\hline \multirow{25}{*}{ Student } & \multirow{4}{*}{ Model Schedule } & \multirow{4}{*}{ Extra Load } & Conflicting Academic Schedules (1) \\
\hline & & & Target Pressure (2) \\
\hline & & & Extra Deliverable (2) \\
\hline & & & Increased Expectations (3) \\
\hline & \multirow{8}{*}{$\begin{array}{l}\text { Model } \\
\text { Flexibility }\end{array}$} & \multirow{8}{*}{$\begin{array}{l}\text { Lacks Numerical } \\
\text { Quantification for } \\
\text { Constructs }\end{array}$} & No Rating Scores for trails (1) \\
\hline & & & Approximation Oriented (1) \\
\hline & & & Highly Qualitative (2) \\
\hline & & & Lack of Correlation Measure (1) \\
\hline & & & $\begin{array}{c}\text { Unavailability of Analysis of Variance } \\
\text { Measure (2) }\end{array}$ \\
\hline & & & $\begin{array}{l}\text { Absence of Standard Deviation measure } \\
\text { for modules (1) }\end{array}$ \\
\hline & & & $\begin{array}{l}\text { Deficit of Testing Scores for Modules } \\
\text { (1) }\end{array}$ \\
\hline & & & $\begin{array}{l}\text { Scarcity of Quantifiable Rankings for } \\
\text { constructs (2) }\end{array}$ \\
\hline & \multirow{6}{*}{$\begin{array}{c}\text { Model } \\
\text { Administration }\end{array}$} & \multirow{6}{*}{ Lack of Adoption } & Lethargy and Procrastination (2) \\
\hline & & & Lack of Respect (2) \\
\hline & & & $\begin{array}{l}\text { Fails to understand Student Psychology } \\
\text { (1) }\end{array}$ \\
\hline & & & $\begin{array}{l}\text { Shortage of Implementation Resources } \\
\text { (2) }\end{array}$ \\
\hline & & & $\begin{array}{l}\text { Lack of Self-Agreement to the concept } \\
\text { (2) }\end{array}$ \\
\hline & & & $\begin{array}{c}\text { Shortcomings of Concept } \\
\text { Understandings (2) }\end{array}$ \\
\hline & \multirow{7}{*}{$\begin{array}{l}\text { Overall Model } \\
\text { Usage, } \\
\text { Relevance and } \\
\text { Applicability }\end{array}$} & \multirow[t]{7}{*}{ Lack of Initiative } & Personal Ignorance (2) \\
\hline & & & Innocence of Individual (2) \\
\hline & & & Deficiency of Trust (2) \\
\hline & & & System Distrust (2) \\
\hline & & & Dearth of Self-esteem (2) \\
\hline & & & Inadequacy of Self-confidence (2) \\
\hline & & & Inherent Phobia (2) \\
\hline
\end{tabular}

In tabular analysis above, critical constituent elements of each analysis criteria under prime focus area and key attributes related are clearly ranked by the focus group through assignment of numerical weights. The appropriation of rankings is witnessed with a strong majority satisfactory and neutral 
levels of satisfaction as compared to the least weightage. The further direct interviews with the focus group revealed that IEDRA Model indeed submits perceivable advantages and applicable benefits for the placement desiring candidates in the campus. The constraints are moderate with neutral weightage as evidenced above in the rankings which further could be turned around towards advantages and benefits of the job seeking students in the campus.

\section{CONCLUSION :}

As concluding remarks, we have studied the determinant issues and various key factors affecting IEDRA Model of campus placement using ABCD analysis framework. The analysis identified numerous key affecting attributes for various determinant issues under four constructs advantages, benefits, constraints, and disadvantages. The analysis has brought about 101 key critical constituent elements under the constructs which satisfy the depth and effectiveness of IEDRA Model. Lastly, the assignment of weightage rankings to 101 key critical constituent elements under the study ascertained the presence of high satisfactory levels of the IEDRA Model which evidences the success for its existence at the service of job seeking students at campus.

\section{REFERENCES :}

[1] Shenoy, Varun., and Aithal, P. S. (2017). A New IEDRA Model for Student Placement Realization (July 28, 2017). International Journal of Management, Technology, and Social Sciences (IJMTS), 2(2), 20-27.

[2] Capps III, C. J., \& Glissmeyer, M. D. (2012). Extending the competitive profile matrix using internal factor evaluation and external factor evaluation matrix concepts. Journal of Applied Business Research, 28(5), 1059.

[3] Kaplan, R., and Norton, D. (1992) The Balanced Scorecard : Measures That Drive Performance. Harvard Business Review Jan-Feb, pp 71-79.

[4] Humphrey, A. S. (2005). SWOT analysis. Long Range Planning, 30, 46-52.

[5] Porter, M. E. (2011). Competitive advantage of nations: creating and sustaining superior performance. Simon and Schuster.

[6] Hax, A. C., \& Majluf, N. S. (1983). The use of the growth-share matrix in strategic planning. Interfaces, 13(1), 46-60.

[7] Singh, A. (2013). A study of role of McKinsey's 7S framework in achieving organizational excellence. Organization Development Journal, 31(3), 39.

[8] Ho, J. K. K. (2014). Formulation of a systemic PEST analysis for strategic analysis. European academic research, 2(5), 6478-6492.

[9] Aithal, P. S., Shailashree, V. T, S., \& Kumar, P. M. (2016). Analysis of ABC Model of Annual Research Productivity using ABCD Framework. International Journal of Current Research and Modern Education (IJCRME), 1(1), 846-858.

[10] Shenoy, Varun., and Aithal, P. S. (2017). A New Box Framework for E-Campus Interview Training. International Journal of Applied Engineering and Management Letters (IJAEML), 1(2), 17-26.

[11] Aithal, P. S., and Shailashree, V. T., and Kumar, P. M. Suresh. (2015). A New ABCD Technique to Analyze Business Models \& Concepts. International Journal of Management, IT and Engineering, 5(4), 409-423.

[12] Aithal, P. S., (2017). ABCD Analysis as Research Methodology in Company Case Studies. International Journal of Management, Technology, and Social Sciences (IJMTS), 2(2), 40-54.

[13] Aithal, P. S. (2016). Study on ABCD Analysis Technique for Business Models, Business Strategies, Operating Concepts \& Business Systems. International Journal in Management and Social Science, 4(1), 1-18. 
[14] Reshma, P.S., and Aithal, P. S., and Acharya, Sridhar. (2015). An Empirical Study on Working from Home : A Popular E-Business Model. International Journal of Advance and Innovative Research, 2(2), 12-18.

[15] Aithal, P. S., and Shailashree, V. T., and Kumar, P. M. Suresh. (2015). Application of ABCD Analysis Model for Black Ocean Strategy. International Journal of Applied Research, 1(10), 331-337.

[16] Aithal, P. S., and Shailashree, V. T., and Kumar, P. M. Suresh. (2016). ABCD Analysis of Stage Model in Higher Education. International Journal of Management, IT and Engineering, 6(1), 1124.

[17] Aithal, P. S., and Shailashree, V. T., and Kumar, P. M. Suresh. (2016). Analysis of NAAC Accreditation System Using ABCD Framework. International Journal of Management, IT and Engineering, 6(1) 30-44.

[18] Aithal, P. S., Shailashree, V. T., \& Kumar, P. M. (2016). Application of ABCD Analysis Framework on Private University System in India. International Journal of Management Sciences and Business Research, 5(4), 159-170.

[19] Aithal, P. S., Shailashree, V. T., \& Kumar, P. S. (2016). ABCD analysis of New National Institutional Ranking System. International Journal of Current Research and Modern Education (IJCRME), 1(1), 2016.

[20] Aithal, Shubhrajyotsna., \& Aithal, P. S. (2016). ABCD analysis of Dye-doped Polymers for Photonic Applications. IRA-International Journal of Applied Sciences, 4(3), 358-378.

[21] Reshma, Aithal P. S., Shailashree V T, Sridhar Acharya, P. (2015). An Empirical study on working from home - A popular E-business model, International Journal of Advance and Innovative Research, 2(2), 12-18. DOI : http://doi.org/10.5281/zenodo.164429.

[22] Aithal, P. S., \& Suresh Kumar, P. M. (2016). Theory A for Optimizing Human Productivity, IRA International Journal of Management \& Social Sciences, 4(3), 526-535. DOI: http://dx.doi.org/10.21013/jmss.v4.n3.p2.

[23] Reshma, Aithal, P. S \& Sridhar Acharya, P. (2015). Relevance of On-line Office Administration through Working from Home in Future Education System. International Journal of Application or Innovation in Engineering \& Management, 4(4), $44-53$. DOI: http://doi.org/10.5281/zenodo.163882.

[24] Padmanabha Shenoy, and Aithal P. S., (2016). A Study on History of Paper and possible Paper Free World. International Journal of Management, IT and Engineering (IJMIE), 6(1), 337-355. DOI: http://doi.org/10.5281/zenodo.161141.

[25] Aithal, P.S., (2015). Comparative Study on MBA Programmes in Private \& Public Universities - A case study of MBA programme plan of Srinivas University. International Journal of Management Sciences and Business Research (IJMSBR), 4(12), 106-122. DOI: http://doi.org/10.5281/zenodo.163884.

[26] Aithal P. S., and Suresh Kumar P. M., (2016). Analysis of Choice Based Credit System in Higher Education. International Journal of Engineering Research and Modern Education (IJERME), 1(1), 278-284. DOI: http://doi.org/10.5281/zenodo.161046.

[27] Varun Shenoy and Aithal, P. S. (2016). Changing Approaches in Campus Placements - A new futuristic Model. International Journal of Scientific Research and Modern Education (IJSRME), 1(1), 766 - 776.DOI : http://doi.org/10.5281/zenodo.160966.

[28] Aithal, P. S. \& Shubhrajyotsna Aithal, (2016). A New Model for Commercialization of Nanotechnology Products and Services. International Journal of Computational Research and Development, 1(1), 84-93. DOI: http://doi.org/10.5281/zenodo.163536. 
[29] Shubrajyotsna Aithal \& Aithal, P. S., (2016). Student Centric Learning through Planned Hardwork - An Innovative Model. International Journal of Scientific Research and Modern Education (IJSRME), 1(1), 886-898. DOI: http://doi.org/10.5281/zenodo.61830.

[30] Sridhar Acharya \& Aithal, P. S. (2017). Electricity from Microbial Fuel Cell- Challenges in Implementing the Cell in Rural India. International Journal of Applied and Advanced Scientific Research (IJAASR), 2(1), 90-93. DOI : http://doi.org/10.5281/zenodo.569764.

[31] Aithal, P. S. (2017). Comparative Study of Various Research Indices used to measure quality of Research Publications. International Journal of Applied and Advanced Scientific Research (IJAASR), 2(1), 81-89. DOI : http://doi.org/10.5281/zenodo.569763.

[32] Architha Aithal, and Aithal, P. S., (2017). ABCD Analysis of Task Shifting - An optimum Alternative Solution to Professional Healthcare Personnel Shortage. International Journal of Health Sciences and Pharmacy (IJHSP), 1(2), 36-51. DOI: http://dx.doi.org/10.5281/zenodo.1038975.

[33] Aithal, P. S., (2017). ABCD Analysis as Research Methodology in Company Case Studies. International Journal of Management, Technology, and Social Sciences (IJMTS), 2(2), 40-54. DOI: http://dx.doi.org/10.5281/zenodo.891621.

[34] Aithal, P. S. (2017). Factor Analysis based on ABCD Framework on Recently Announced New Research Indices, International Journal of Management, Technology, and Social Sciences (IJMTS), 1(1), 82-94. DOI: http://dx.doi.org/10.5281/zenodo.584105.

[35] Aithal, P. S. (2017). ABCD Analysis of Recently Announced New Research Indices. International Journal of Management, Technology, and Social Sciences (IJMTS), 2(1), 65-76. DOI: http://doi.org/10.5281/zenodo.583644.

[36] Aithal, P. S. Shailashree, V. T. \& Suresh Kumar, P. M. (2016). ABCD analysis of Stage Model in Higher Education, International Journal of Management, IT and Engineering (IJMIE), 6(1), 11-24, DOI : http://doi.org/10.5281/zenodo.154233.

[37] Aithal, P. S. Shailashree, V. T. \& Suresh Kumar, P. M. (2016). Analysis of NAAC Accreditation System using ABCD framework, International Journal of Management, IT and Engineering (IJMIE), 6(1), 30 - 44, DOI : http://doi.org/10.5281/zenodo.154272.

[38] Aithal, P. S. \& Suresh Kumar, P. M. (2016). CCE Approach through ABCD Analysis of 'Theory A' on Organizational Performance. International Journal of Current Research and Modern Education (IJCRME), 1(2), 169-185. DOI: http://dx.doi.org/10.5281/ZENODO.164704.

[39] Aithal, P. S., Shailashree V. T. \& Suresh Kumar P.M. (2016). Factors \& Elemental Analysis of Six Thinking Hats Technique using ABCD Framework. International Journal of Advanced Trends in Engineering and Technology (IJATET), 1(1), 85-95. DOI : http://doi.org/10.5281/zenodo.240259. 